\title{
BMJ
}

\section{Effect of training and lifting equipment for preventing back pain in lifting and handling: systematic review}

\author{
Kari-Pekka Martimo, medical specialist, ${ }^{1}$ Jos Verbeek, team leader, ${ }^{2}$ Jaro Karppinen, medical specialist, ${ }^{3}$ \\ Andrea D Furlan, associate scientist, ${ }^{4}$ Esa-Pekka Takala, medical specialist, ${ }^{1}$ P Paul F M Kuijer, senior \\ researcher, ${ }^{5}$ Merja Jauhiainen, information specialist, ${ }^{6}$ Eira Viikari-Juntura, research professor ${ }^{1}$
}

\begin{abstract}
${ }^{1}$ Musculoskeletal Disorders Group Centre of Expertise for Health and Work Ability, Finnish Institute of Occupational Health, Helsinki,

Finland

${ }^{2}$ Knowledge Transfer in

Occupational Health and Safety

Group, Centre of Expertise for

Good Practices and Competence,

Finnish Institute of Occupational

Health, Kuopio, Finland

${ }^{3}$ Musculoskeletal Disorders

Group, Centre of Expertise for

Health and Work Ability, Finnish

Institute of Occupational Health, Oulu, Finland

${ }^{4}$ Institute for Work and Health,

Toronto, Canada

${ }^{5}$ Coronel Institute of Occupational Health, Academic Medical Centre,

University of Amsterdam,

Amsterdam, the Netherlands

${ }^{6}$ Knowledge Transfer in

Occupational Health and Safety

Group, Centre of Expertise for

Good Practices and Competence,

Finnish Institute of Occupational

Health, Helsinki, Finland

Correspondence to: K P Martimo

kari-pekka.martimo@ttl.fi
\end{abstract}

doi:10.1136/bmj.39463.418380.BE

\section{ABSTRACT}

Objectives To determine whether advice and training on working techniques and lifting equipment prevent back pain in jobs that involve heavy lifting.

Data sources Medline, Embase, CENTRAL, Cochrane Back Group's specialised register, CINAHL, Nioshtic, CISdoc, Science Citation Index, and PsychLIT were searched up to September-November 2005.

Review methods The primary search focused on randomised controlled trials and the secondary search on cohort studies with a concurrent control group.

Interventions aimed to modify techniques for lifting and handling heavy objects or patients and including measurements for back pain, consequent disability, or sick leave as the main outcome were considered for the review. Two authors independently assessed eligibility of the studies and methodological quality of those included. For data synthesis, we summarised the results of studies comparing similar interventions. We used odds ratios and effect sizes to combine the results in a meta-analysis.

Finally, we compared the conclusions of the primary and secondary analyses.

Results Six randomised trials and five cohort studies met the inclusion criteria. Two randomised trials and all cohort studies were labelled as high quality. Eight studies looked at lifting and moving patients, and three studies were conducted among baggage handlers or postal workers. Those in control groups received no intervention or minimal training, physical exercise, or use of back belts. None of the comparisons in randomised trials (17 720 participants) yielded significant differences. In the secondary analysis, none of the cohort studies (772 participants) had significant results, which supports the results of the randomised trials.

Conclusions There is no evidence to support use of advice or training in working techniques with or without lifting equipment for preventing back pain or consequent disability. The findings challenge current widespread practice of advising workers on correct lifting technique.

\section{INTRODUCTION}

Heavy lifting at work increases the risk of back pain. ${ }^{1}$ Optimal working techniques are encouraged to prevent back pain and injuries when lifting heavy loads or patients cannot be avoided. ${ }^{23}$ In addition, lifting equipment has been developed to relieve some of the workload.

Back pain is highly prevalent. The resulting disability has enormous consequences in terms of distress and economic costs of absence from work and reduced productivity. ${ }^{4}$ Employers must ensure that workers receive proper training and information on how to handle loads correctly and the risks to which they might be exposed. ${ }^{5}$ Specific techniques have been advocated to reduce the load on the back. ${ }^{67}$

Earlier reviews on occupational interventions have questioned the role of education in the prevention of work related back pain. ${ }^{89}$ Even though primary studies have found no effect of training on the incidence of back pain, this could be incidental or caused by small sample size. We therefore carried out a review following the systematic and more rigorous Cochrane methods in searching the literature, selecting interventions and study designs, and combining the results.

\section{METHODS}

\section{Searching}

With the primary focus on randomised controlled trials, we used the search strategy developed by the Cochrane back review group. ${ }^{10}$ From August to November 2005 we searched Medline, Embase, CENTRAL, the back group's specialised register, CINAHL, Nioshtic, CISdoc, Science Citation Index, and PsychLIT. Detailed search strategies are given elsewhere. ${ }^{11}$ We considered trials reported in any language.

In a secondary analysis using relevant cohort studies with concurrent control groups, we applied the sensitive search strategy for occupational health intervention studies ${ }^{12}$ in Medline until November 2005.

\section{Selection, validity assessment, and data abstraction}

Two authors (EPT, JK) screened the obtained titles and abstracts for eligibility. Eligible studies were those that aimed to modify the participants' lifting techniques at work and measured back pain, consequent disability, or sickness absence as the main outcomes. 
Two other authors (KPM, JV) independently assessed methodological quality of the randomised trials using the criteria and classification recommended by the Cochrane back review group. ${ }^{10}$ Studies were considered as high quality if more than half of the criteria were fulfilled. For the appraisal of cohort studies we used another instrument validated for nonrandomised studies. ${ }^{13}$ Disagreements between assessments were resolved by discussion until consensus was reached. KPM and JV also independently extracted the data as recommended by the Cochrane back review group. $^{10}$

\section{Study characteristics}

Our primary analysis was based on evidence from randomised trials only. In the secondary analysis using the cohort studies, we summarised the results of each comparison in a qualitative manner. Thereafter, we compared the conclusions from the primary and secondary analyses.

\section{Quantitative data synthesis}

For studies that did not adjust for cluster randomisation, we calculated the design effect based on a fairly large assumed intracluster correlation of $0.10,{ }^{14}$ following the methods stated in the Cochrane handbook. ${ }^{15}$ We categorised the length of follow-up as short term (less than three months), intermediate (three to 12 months), or long term (more than 12 months). This classification is used for the description of the results.

For comparisons with dichotomous outcomes and sufficient data, we plotted the adjusted results of each

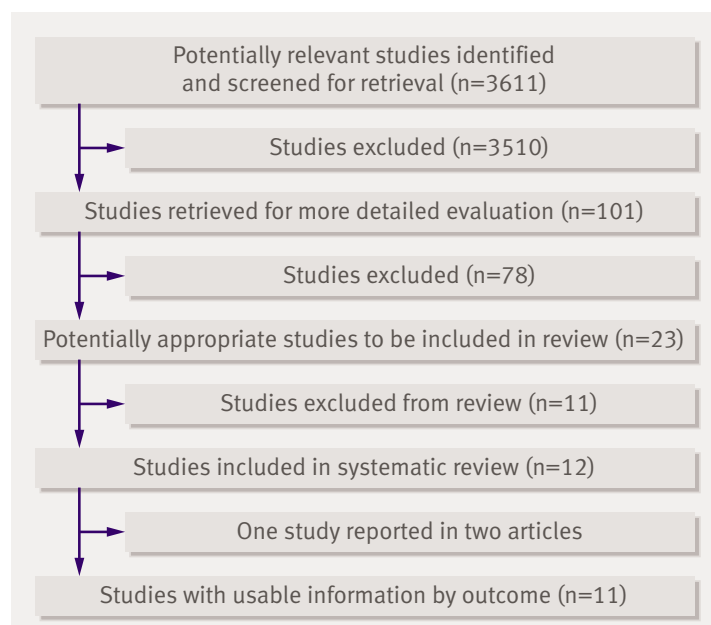

Fig 1 Review flow chart

trial as odds ratios. For comparisons with similar interventions but with both dichotomous and continuous outcome measurements, we calculated an effect size based on the logarithm of the odds ratio for studies with dichotomous outcomes, and on the standardised mean difference for studies with continuous outcomes. ${ }^{16}$ We combined the odds ratios of studies that compared similar interventions and measured back pain or back injury at a similar follow-up time. We combined effect sizes of studies with similar interventions that measured sickness absence rate or

\begin{tabular}{|c|c|c|c|c|c|}
\hline Study & Design, participants & Intervention $v$ control & Length of follow-up & Outcomes & $\begin{array}{l}\text { Methodological } \\
\text { quality }\end{array}$ \\
\hline Daltroy 1997, USA $^{\text {w3 }}$ & $\begin{array}{l}\text { Cluster randomised } 3597 \\
\text { postal workers }\end{array}$ & $\begin{array}{l}\text { Training and ergonomic site visit } v \\
\text { standard training (video) }\end{array}$ & 5.5 years & $\begin{array}{l}\text { Back injury rate (disabling and non- } \\
\text { disabling) per } 1000 \text { worker years of } \\
\text { exposure }\end{array}$ & $\operatorname{High}(6 / 11)$ \\
\hline Kraus 2002, USA ${ }^{\mathrm{w} 4}$ & $\begin{array}{l}\text { Cluster randomised, } 12772 \\
\text { home care workers }\end{array}$ & $\begin{array}{l}\text { Safety meeting } v \text { back belt, no } \\
\text { intervention }\end{array}$ & 28 months & $\begin{array}{l}\text { Back injury rate per } 100 \text { full time } \\
\text { equivalents }\end{array}$ & Low $(5 / 11)$ \\
\hline $\begin{array}{l}\text { van Poppel } 1998, \\
\text { Netherlands }^{\text {w5 }}\end{array}$ & $\begin{array}{l}\text { Cluster randomised, } 312 \\
\text { cargo handlers }\end{array}$ & $\begin{array}{l}\text { Training } v \text { lumbar support, lumbar } \\
\text { support and training, no } \\
\text { intervention }\end{array}$ & 6 months & $\begin{array}{l}\text { No of subjects with low back pain; No of } \\
\text { subjects with sick leave and No of days } \\
\text { per month with low back pain; No of } \\
\text { days per month of sick leave because of } \\
\text { low back pain }\end{array}$ & High $(8 / 11)$ \\
\hline Yassi 2001, Canadaw6 & $\begin{array}{l}\text { Cluster randomised, } 346 \\
\text { nurses }\end{array}$ & $\begin{array}{l}\text { "No strenuous lifting" v"safe } \\
\text { lifting" programme, "usual } \\
\text { practice" }\end{array}$ & 1 year & $\begin{array}{l}\text { Experienced work related low back pain } \\
\text { and its intensity during past week; } \\
\text { Oswestry disability questionnaire; rate } \\
\text { of back or trunk related injuries }\end{array}$ & Low $(4 / 11)$ \\
\hline Müller 2001, Germanyw7 & Randomised, 51 nurses & Training $v$ exercise in space curl & 12 months & Frequency of low back pain & Low $(3 / 11)$ \\
\hline Reddel 1992, USA ${ }^{\text {w8 }}$ & $\begin{array}{l}\text { Randomised, } 642 \text { fleet service } \\
\text { clerks }\end{array}$ & $\begin{array}{l}\text { Training } v \text { back belt, back belt and } \\
\text { training, no intervention }\end{array}$ & 8 months & Back injury rate (no raw data available) & Low $(2 / 11)$ \\
\hline Fanello 1999, France ${ }^{\mathrm{w} 1}$ & $\begin{array}{l}\text { Cohort study, } 272 \text { nurses and } \\
\text { cleaners }\end{array}$ & $\begin{array}{l}\text { Training and feedback at work } v \text { no } \\
\text { intervention }\end{array}$ & 2 years & Prevalence of low back pain & High $(8 / 12)$ \\
\hline 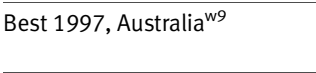 & Cohort study, 55 nurses & Training $v$ in-house orientation & 12 months & $\begin{array}{l}\text { Self reported low back pain during past } \\
\text { week and past year }\end{array}$ & High $(8 / 12)$ \\
\hline Dehlin 1981, Sweden ${ }^{\text {w10 }}$ & Cohort study, 45 nurses & $\begin{array}{l}\text { Training } v \text { physical exercise, no } \\
\text { intervention }\end{array}$ & 8 weeks & Frequency of low back symptoms & $\operatorname{High}(7 / 12)$ \\
\hline Feldstein 1993, USA ${ }^{\text {w11 }}$ & Cohort study, 55 nurses & $\begin{array}{l}\text { Training, practical feedback } v \text { no } \\
\text { intervention }\end{array}$ & 1 month & "Composite back pain" & $\operatorname{High}(7 / 12)$ \\
\hline Hartvigsen 2005, Denmark w12 & Cohort study, 345 nurses & $\begin{array}{l}\text { Training } v \text { one instructional } \\
\text { meeting }\end{array}$ & 2 years & $\begin{array}{l}\text { No of episodes and No of days with low } \\
\text { back pain during past year }\end{array}$ & High $(9 / 12)$ \\
\hline
\end{tabular}


Table 2 Details of interventions in studies aimed at preventing back injury and pain caused by lifting and handling patients or heavy objects

\begin{tabular}{|c|c|c|c|c|c|c|c|c|}
\hline Study & $\begin{array}{l}\text { No and duration of } \\
\text { sessions }\end{array}$ & $\begin{array}{l}\text { Time span of } \\
\text { training }\end{array}$ & Training as described in article & $\begin{array}{l}\text { Training } \\
\text { methods* }\end{array}$ & $\begin{array}{l}\text { Management } \\
\text { commitment }\end{array}$ & $\begin{array}{l}\text { Use of } \\
\text { assistive } \\
\text { devices }\end{array}$ & $\begin{array}{l}\text { Ergonomic } \\
\text { intervention } \\
\text { (s) included }\end{array}$ & $\begin{array}{l}\text { Reinforce- } \\
\text { ment } \\
\text { included }\end{array}$ \\
\hline Daltroy $^{\text {w3 }}$ & $2 \times 1.5$ hours & 1 week & Proper lifting and carrying techniques & B & Yes & No & Yes & Yes \\
\hline Kraus $^{\text {w4 }}$ & Unclear & Unclear & Safety practices when handling patients & Unclear & Not mentioned & No & No & No \\
\hline van Poppel ${ }^{\mathrm{w5}}$ & $3 \times 1.5-2$ hours & 12 weeks & Anatomy and lifting techniques & $\mathrm{B}$ & Not mentioned & No & No & No \\
\hline Yassiw6 $^{\text {w6 }}$ & $1 \times 3$ hours & Single training & $\begin{array}{l}\text { "Safe lifting" or "no strenuous lifting." Handling } \\
\text { techniques coupled with available } \\
\text { equipment }\end{array}$ & $\mathrm{B}$ & Not mentioned & Encouraged & No & No \\
\hline Müller $^{w 7}$ & Unclear & Unclear & Unclear & Unclear & Not mentioned & Unclear & Unclear & Unclear \\
\hline Reddel $^{\mathrm{w} 8}$ & $1 \times 1$ hour & Single training & $\begin{array}{l}\text { Balancing load, pivoting instead of twisting, } \\
\text { getting close to load, squat lift, squaring load, } \\
\text { maintaining three point contact }\end{array}$ & $\mathrm{B}$ & Not mentioned & No & No & No \\
\hline Best $^{\text {w9 }}$ & 32 hours (in total) & Unclear & $\begin{array}{l}\text { Semisquat posture and weight transfer } \\
\text { techniques such as bracing, pivoting, lunging, } \\
\text { and counterbalancing load }\end{array}$ & Unclear & Not mentioned & No & No & No \\
\hline Dehlinw10 $^{\text {w10 }}$ & $8 \times 45 \min$ & 8 weeks & $\begin{array}{l}\text { Short lever arms during lifting, minimising } \\
\text { weight of burden by lifting together }\end{array}$ & A & Not mentioned & Encouraged & No & No \\
\hline Fanellow1 $^{\text {w1 }}$ & 6 (length unclear) & 6 days & $\begin{array}{l}\text { Method revised by Paul Dotte as applied also } \\
\text { by Best et al }{ }^{\text {w9 }}\end{array}$ & Unclear & Not mentioned & Encouraged & No & Yes \\
\hline Feldstein $^{\text {w11 }}$ & $1 \times 2+8$ hours & 2 weeks & Specific technique for patient transfer & $\mathrm{B}$ & Yes & Encouraged & No & No \\
\hline Hartvigsen $^{\text {w12 }}$ & $\begin{array}{c}104 \times 1 \text { hour }+4 \times 2 \\
\text { hours }\end{array}$ & 2 years & "Bobath principle" & $\mathrm{B}$ & Yes & Encouraged & No & Yes \\
\hline
\end{tabular}

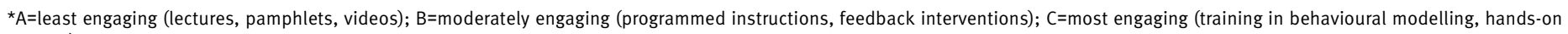
training).

disability score at a similar follow-up time by using the generic inverse variance method. For both metaanalyses we used the software as implemented in RevMan 4.2.

\section{RESULTS}

\section{Trial flow}

With our primary search strategy we found 3547 titles in nine databases. The sensitive search strategy provided 47 additional titles and a manual search provided another 17. From these 3611 articles, we closely evaluated 101 (fig 1). Eighty nine articles did not meet the inclusion criteria. Two articles reported on the same study. ${ }^{\text {w1 w2 }}$ Consequently, we included 11 studies in the review.

\section{Study characteristics}

Four of the included studies were cluster randomised, ${ }^{\text {w3-w6 }}$ two were individually randomised, ${ }^{\text {w7 }}{ }^{\text {w8 }}$ and five were cohort studies. ${ }^{\text {w1 w9-w12 }}$ Table 1 shows the characteristics of the included studies.

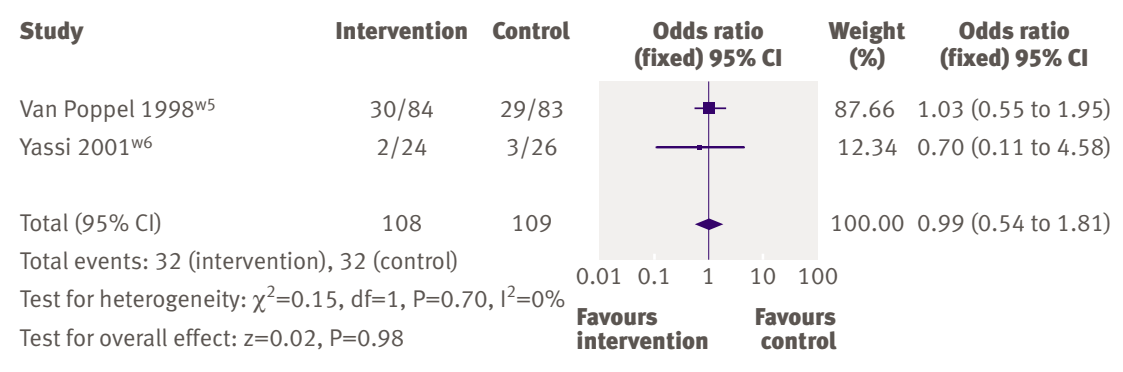

Fig 2 Meta-analyses of two trials (adjusted for effect of clustering) on advice on lifting and handling compared with no advice in prevention of back pain or back injury at intermediate follow-up
Three randomised trials ${ }^{\mathrm{w} 4 \mathrm{w} 6 \mathrm{w} 7}$ and all five cohort studies involved care of patients. One trial studied postal workers, ${ }^{\text {w3 }}$ and two studied baggage handlers. ${ }^{\text {w5 }}$ w8 The number of participants in randomised trials varied from 51 to 12772 , and the follow-up time from six months to 5.5 years. The numbers in the cohort studies varied from 45 to 345 , and the follow-up times ranged from eight weeks to two years.

We had originally intended to include only prevention studies with workers without back pain. This proved to be impractical because there were always some workers with back pain at baseline. We therefore included studies with workers who were not actively seeking treatment for current back pain. In all jobs studied, the participants had enough strain on the back such that effective interventions could result in alleviation of symptoms.

The training interventions (table 2) focused on lifting techniques, with duration varying from a single session $^{\text {w6 w8 w11 }}$ to training once a week for two years. ${ }^{\text {w12 }}$ In three studies the training was supported by followup and feedback at the workplace. ${ }^{\text {w1 w3 w12 }}$ The advocated lifting techniques were not described in detail. Three studies clearly indicated the involvement of supervisors, ${ }^{\text {w3 w11 w12 }}$ and five studies encouraged participants to use available lifting aids. ${ }^{\text {w1 w6 w10 w11 w12 }}$ Most studies used a professional instructor. ${ }^{\mathrm{w} 1 \mathrm{w} 3 \mathrm{w} 5 \mathrm{w} 8 \mathrm{w10} \text { w11 }}$

Five studies monitored compliance with the instructions and with the use of lifting equipment. ${ }^{\mathrm{w} 5} \mathrm{w} 6 \mathrm{w} 9 \mathrm{w} 11 \mathrm{w} 12$ The results indicated positive changes in lifting techniquein three studies and marginal or no changes in two studies. Daltroy et al reported separately that the intervention resulted in increased knowledge but not in 


\begin{tabular}{|c|c|c|c|}
\hline & \multicolumn{2}{|c|}{ Randomised controlled studies } & \multirow{2}{*}{$\begin{array}{l}\text { Cohort studies (all high } \\
\text { quality) }\end{array}$} \\
\hline & High quality & Low quality & \\
\hline \multicolumn{4}{|c|}{ Manual handling advice $v$ no intervention } \\
\hline \multicolumn{4}{|l|}{ Outcome-back pain: } \\
\hline Short term follow-up & NA & NA & $\mathrm{NS}^{\mathrm{w} 10, \mathrm{w} 11}$ \\
\hline Intermediate follow-up & $\mathrm{NS}^{\mathrm{w} 5}$ & $N S^{w 6, w 8}$ & NA \\
\hline Long term follow-up & NA & $\mathrm{NS}^{\mathrm{w} 4}$ & $\mathrm{NS}^{\mathrm{w} 1}$ \\
\hline \multicolumn{4}{|l|}{ Outcome-disability } \\
\hline Intermediate follow-up & $\mathrm{NS}^{\mathrm{w} 5}$ & NS ${ }^{w 6}$ & NA \\
\hline \multicolumn{4}{|c|}{ Manual handling advice $v$ minor advice } \\
\hline \multicolumn{4}{|l|}{ Outcome-back pain: } \\
\hline Intermediate follow-up & NA & NA & $\mathrm{NS} \mathrm{w}^{\mathrm{w}}$ \\
\hline Long term follow-up & $\mathrm{NS}^{\mathrm{w} 3}$ & NA & $\mathrm{NS}^{\mathrm{w12}}$ \\
\hline \multicolumn{4}{|c|}{ Manual handling advice $v$ use of back belt } \\
\hline \multicolumn{4}{|l|}{ Outcome-back pain: } \\
\hline Intermediate follow-up & NA & $\mathrm{NS}^{\mathrm{w} 8}$ & NA \\
\hline Long term follow-up & NA & $\mathrm{NS}^{\mathrm{w} 4}$ & NA \\
\hline \multicolumn{4}{|c|}{ Manual handling advice $v$ physical exercise } \\
\hline \multicolumn{4}{|l|}{ Outcome-back pain: } \\
\hline Short term follow-up & NA & NA & $\mathrm{NS}^{\mathrm{w10}}$ \\
\hline Intermediate follow-up & NA & $\mathrm{NS}^{\mathrm{w} 7}$ & NA \\
\hline \multicolumn{4}{|c|}{ Advice and assistive devices $v$ no intervention or advice only } \\
\hline \multicolumn{4}{|c|}{ Outcome-back pain/disability } \\
\hline Intermediate follow-up & NA & $\mathrm{NS}^{\mathrm{w} 6}$ & NA \\
\hline
\end{tabular}

significant improvement in lifting and handling technique. ${ }^{17}$

Two randomised trials ${ }^{\mathrm{w} 3 \mathrm{w} 5}$ and all cohort studies were classed as high quality (table 1 ). Full details can be found elsewhere. ${ }^{11}$

\section{Quantitative data synthesis}

Comparison between the groups that received training or no intervention in two randomised trials indicated that there was no difference in back pain (odds ratio $0.99,95 \%$ confidence interval 0.54 to 1.81 ) or related disability (effect size $0.04,-0.50$ to 0.58 ) at intermediate follow-up (figs 2 and 3).,5w6 The same result was obtained in another randomised trial, ${ }^{\text {w8 }}$ which we did

\begin{tabular}{|c|c|c|c|c|c|}
\hline Study & Effect size (SE) & $\begin{array}{r}\text { Effect si } \\
\text { (fixed) } 95\end{array}$ & ize & $\begin{array}{c}\text { Weight } \\
\text { (\%) }\end{array}$ & $\begin{array}{c}\text { Effect size } \\
\text { (fixed) } 95 \% \mathrm{Cl}\end{array}$ \\
\hline Van Poppel 1998w5 & $-0.2230(0.5167)$ & $\rightarrow$ & & 28.54 & $-0.22(-1.24$ to 0.79$)$ \\
\hline Yassi 2001w6 & $0.1500(0.3265)$ & - & & 71.46 & 0.15 (-0.49 to 0.79$)$ \\
\hline Total $(95 \% \mathrm{Cl})$ & & - & & 100.00 & $0.04(-0.50$ to 0.58$)$ \\
\hline Test for heterogeneit & $1, P=0.54, I^{2}=0 \%$ & & & & \\
\hline Test for overall effect & & $\begin{array}{lll}1 & 0.1 & 1 \\
\text { ours } \\
\text { ervention }\end{array}$ & $\begin{array}{l}10 \\
\text { Favo } \\
\text { con }\end{array}$ & & \\
\hline
\end{tabular}

Fig 3 Meta-analyses of two trials (adjusted for effect of clustering) on advice on lifting and handling compared with no advice in prevention of back related disability or sickness absence at intermediate follow-up not include in the meta-analysis because insufficien data were reported (table 3 ). One randomised trial showed no effect on back pain at long term follow-up (odds ratio 1.07, 0.06 to 17.96) (fig 4). ${ }^{\mathrm{w} 4}$ The results of three cohort studies supported those of the randomised studies at short term ${ }^{\mathrm{w} 10 \mathrm{w} 11}$ and long term follow-up ${ }^{\mathrm{w} 1}$ (table 3).

One randomised trial found no effect of training on back pain compared with minor advice (video) at long term follow-up (odds ratio 1.08, 95\% confidence interval 0.56 to 2.08 ) (fig 4). ${ }^{\text {w3 }}$ This was supported by the results of two cohort studies that used in-house orientation or less extensive training as the control interventions (table 3). ${ }^{\mathrm{w} 9} \mathrm{w} 12$

One randomised trial found no significant difference in back pain with training compared with use of back belts at intermediate follow-up (table 3). w8 Another randomised trial had similar conclusions at long term follow-up (1.04, 0.06 to 17.38) (fig 4). ${ }^{\mathrm{w} 4}$

One randomised trial that compared training with physical exercise found no difference in back pain at intermediate follow-up (table 3). ${ }^{\text {77 }}$ The results of one cohort study supported the conclusions at short term follow-up (table 3). w10

A comparison of a group receiving training and lifting equipment with the groups receiving training only or no intervention at all in one randomised trial showed no difference in back pain at intermediate 


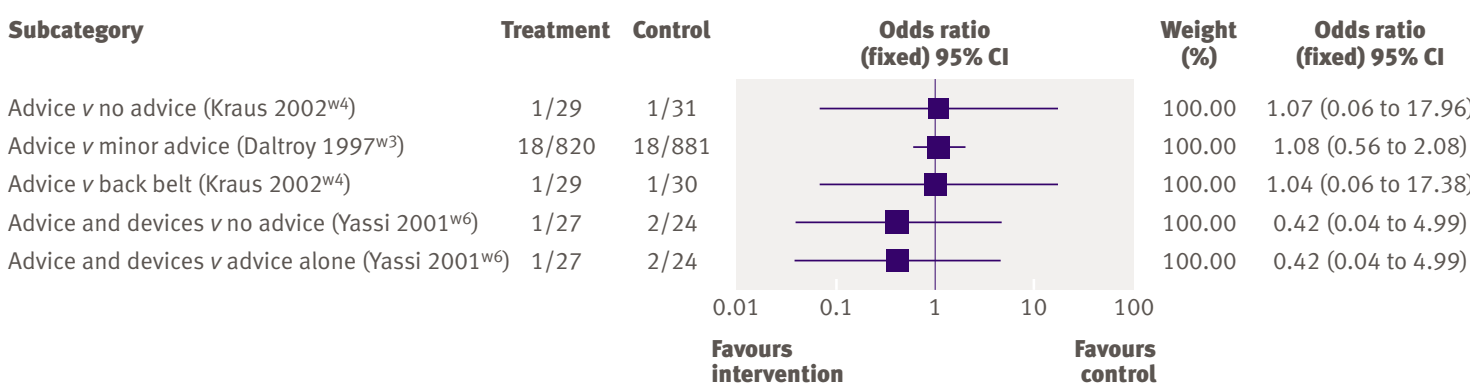

Fig 4 Odds ratios of trials (adjusted for effect of clustering) that studied advice and training with or without lifting equipment (devices) to prevent back pain or back injury at intermediate or long term follow-up

follow-up of either comparison (0.42, 0.04 to 4.99) (fig 4). ${ }^{\mathrm{w} 6}$ There was also no difference in back related disability (table 3).

\section{DISCUSSION}

In this systematic review we found no evidence that training with or without lifting equipment is effective in the prevention of back pain or consequent disability. Either the advocated techniques did not reduce the risk of back injury or training did not lead to adequate change in lifting and handling techniques.

\section{Strengths and limitations}

We included only studies with designs that are the least susceptible to bias. In addition, we compared these results with those of studies with less valid study designs. There were no differences in conclusions between the analyses from studies with different designs or with different types of lifting and handling.

The measurement of the outcomes in the primary studies varied, leading to considerable differences in the incidences of back pain (Kraus et al reported 1.28 back injuries per 100 person years, ${ }^{\text {w4 }}$ Yassi et al reported 7.4 back related injuries per 100 person years, ${ }^{\text {w6 }}$ and van Poppel et al reported 70 cases of self reported back pain per 100 person years ${ }^{\mathrm{w} 5}$ ). Another limitation was that we could not extract the data needed from all studies, limiting the possibilities of pooling data. In addition, we had to adjust the results of most of the studies for the effect of the cluster randomisation that was not taken into account by the authors.

\section{Interpretation}

The actual number of participants in the eligible randomised trials was 17720 . After adjustment for the unit of analysis error, the effective sample size was 2727. The confidence intervals show that we cannot exclude the possibility that the studies and the review lacked the power to detect a small but possibly relevant difference in incidence. It is, however, highly unlikely that pooling the results of more studies would have led to a significant beneficial effect. This is because almost all studies showed an odds ratio that was near to 1 , and the applied comparisons were all quite similar, especially as use of a back belt can be considered equal to no intervention in the prevention of back pain. ${ }^{18}$ Only one study showed a more positive, but still non-significant, outcome. ${ }^{\mathrm{w} 6}$ This could be because the type of the intervention was different ("no strenuous lifting").

One explanation for the lack of an effect could be that the intervention was not appropriate. According to Burke et al, as training methods become more engaging, workers acquire more knowledge and the number of injuries falls. ${ }^{19}$ Accordingly, we classified the training methods based on learners' participation, but we did not find a more positive outcome for studies that involved more intense training methods.

The risk of back pain might be related not to incorrect handling techniques but to other work related factors inherent in the populations studied (such as non-neutral, bent, or rotated trunk postures without lifting or handling, or psychosocial strain). We were unable to test this hypothesis, however, because none of the studies described the context of the intervention in sufficient detail to enable further analysis.

Two randomised controlled trials that lend support to our results have been published recently. One showed no effect on back pain of training in transfer techniques among those looking after elderly people after two years' follow-up. ${ }^{20}$ In the other trial, behaviour based training on lifting in a distribution centre did not result in a difference in rates of back injury during one year of follow-up. ${ }^{21}$

Many health professionals are involved in training and advising workers on lifting and handling. Even though there may be other reasons to continue this practice, this review does not provide evidence that it prevents back pain. There is a need for more and high quality research with standardised outcome

\section{WHAT IS ALREADY KNOWN ON THIS TOPIC}

Training in correct working techniques and lifting equipment is widely used to manage the increased risk of back pain related to repeated heavy lifting and handling

The effectiveness of these interventions has been questioned

\section{WHAT THIS STUDY ADDS}

There is no evidence that advice on lifting and handling with or without lifting equipment prevents back pain or consequent disability 
measurement, appropriate power, and adjustment for the cluster effect. Such studies should be directed at a "no lifting policy." Also we need a better understanding of the causal chain between exposure to biomechanical stressors at work and the subsequent development of back pain to enable the development of new and innovative ways to prevent back pain.

We thank the Cochrane Occupational Health Field for organising and supporting this review. We also thank John Wiley for permission to publish this paper, which is based on a Cochrane review. ${ }^{11}$

Contributors: K-PM organised the daily project activities, did the data extraction, wrote drafts of the review, and is guarantor. JV had the idea for the project, organised funding, performed the data extraction and statistical analyses, and is guarantor. MJ developed and performed the literature searches. JK and E-PT carried out the selection of references and provided input on drafts of the paper. PPFMK, ADF, and EV-J contributed to the data extraction and provided scientific input on the drafts of the paper. Funding: Commonwealth of Australia as represented by and acting through the Department of Employment and Workplace Relations. The Office of the Australian Safety and Compensation Council (OASCC) is the direct supporter and is part of the Department of Employment and Workplace Relations and supports the Australian Safety and Compensation Council.

Competing interests: None declared.

Ethical approval: Not required.

Provenance and peer review: Not commissioned; externally peer reviewed.

1 Kuiper JI, Burdorf A, Verbeek JH, Frings-Dresen M, van $\operatorname{der} B$ Beek AJ, Viikari-Juntura ER. Epidemiologic evidence on manual handling as a risk factor for back disorders: a systematic review. Int J Ind Ergon 1999;24:389-404.

2 Straker LM. A review of research on techniques for lifting low-lying objects. 1. Criteria for evaluation. Work 2002;19:9-18.

3 Straker LM. A review of research on techniques for lifting low-lying objects. 2. Evidence for a correct technique. Work 2002;20:83-96.

4 Maniadakis N, Gray A. The economic burden of back pain in the UK. Pain 2000;84:93-103.

5 Minimum health and safety requirements for the manual handling of loads where there is a risk particularly of back injury to workers. Council Directive 90/269/EEC of 29 May 1990.

6 European Agency for Safety and Health at Work. Hazards and risks associated with manual handling of loads in the workplace. 2007. http://osha.europa.eu/publications/factsheets/73.

7 National Institute for Occupational Safety and Health. Simple solutions for lifting, holding, and handling materials. Introduction. In:
Simple solutions: ergonomics for construction workers. 2007. (NIOSH Publication No 2007-122.) www.cdc.gov/niosh/docs/2007-122/.

8 Van Poppel MNM, Hooftman WE, Koes BW. An update of a systematic review of controlled clinical trials on the primary prevention of back pain at the workplace. Occup Med 2004:54;345-52.

9 Bos EH, Krol B, van der Star A, Groothoff JW. The effects of occupational interventions on reduction of musculoskeletal symptoms in the nursing profession. Ergonomics 2006;49:706-23.

10 Van Tulder MW, Furlan A, Bombardier C, Bouter L, editorial board of the Cochrane Collaboration Back Review Group. Updated method guidelines for systematic reviews in the Cochrane Collaboration back review group. Spine 2003;28:1290-9.

11 Martimo KP, Verbeek J, Karppinen J, Furlan AD, Kuijer PPFM, Viikari-Juntura E, et al. Manual material handling advice and assistive devices for preventing and treating back pain in workers. Cochrane Database Syst Rev 2007;(3):CD005958.

12 Verbeek J, Salmi J, Pasternack I, Jauhiainen M, Laamanen I, Schaafsma F, et al. A search strategy for occupational health intervention studies. Occup Environ Med 2005;62:682-7.

13 Slim K, Nini E, Forestier D, Kwiatkowski F, Panis Y, Chipponi J. Methodological index for non-randomised studies (MINORS): development and validation of a new instrument. Aust NZ J Surg 2003;73:712-6.

14 Campbell MK, Mollison J, Grimshaw JM. Cluster trials in implementation research: estimation of intra-cluster correlation and sample size. Stat Med 2001;20:391-9.

15 Deeks JJ, Higgins JP, Altman DG. Special topics. In: Higgins JPT, Green S, eds. Cochrane handbook for systematic reviews of interventions 4.2.5. [updated May 2005];8.11. www.cochrane.org/resources/handbook/hbook.htm.

16 Chinn S. A simple method for converting an odds-ratio to effect size for use in meta-analysis. Stat Med 2000;19:3127-31.

17 Daltroy LH, Iversen MD, Larson MG, Ryan J, Zwerling C, Fossel AH, et al. Teaching and social support: effects on knowledge, attitudes, and behaviors to prevent low back injuries in industry. Health Educ $Q$ 1993;20:43-62.

18 Jellema P, van Tulder M, van Poppel M, Nachemson A, Bouter L Lumbar supports for prevention and treatment of low back pain: a systematic review within the framework of the Cochrane back review group. Spine 2001;26:377-86.

19 Burke MJ, Sarpy SA, Smith-Crowe K, Chan-Serafin S, Salvador RO, Islam G. Relative effectiveness of worker safety and health training methods. Am J Public Health 2006;96:315-24.

20 Jensen LD, Gonge H, Jors E, Ryom P, Foldspang A, Christensen M, et al. Prevention of low back pain in female eldercare workers: randomised controlled work site trial. Spine 2006;31:1761-9.

21 Lavender SA, Lorenz EP, Andersson GBJ. Can a new behaviourally oriented training process to improve lifting technique prevent occupationally related back injuries due to lifting? Spine 2007;32:487-94.

Accepted: 27 November 2007 